\title{
Isolation and identification of fungal assemblages in the necrotic spots of Bambusa pallida (L.) Voss
}

Sanjit Debnath ${ }^{1 *}$, Pintu Karmakar ${ }^{1}$, Sukla Bhattacharjee ${ }^{1}$, Koushik Majumdar ${ }^{2}$, Panna Das ${ }^{3}$ and Ajay Krishna Saha ${ }^{1}$

${ }^{1}$ Mycology and Plant Pathology Laboratory, Department of Botany, Tripura University, Suryamaninagar-799 022 , Tripura, India

${ }^{2}$ Centre for Bamboo Cultivation and Resource Utilization (BCRU), Department of Botany, Tripura University, Suryamaninagar-799 022, Tripura, India

${ }^{3}$ Microbiology Laboratory, Department of Botany, Tripura University, Suryamaninagar-799 022, Tripura, India.

Received:3/14/2018; Accepted:3/20/2018

\begin{abstract}
Bamboos are the most important plant due to their different uses and good source of income for upliftment of rural economy. Different parts of bamboos are damaged by many harmful bacteria, fungi and other organisms causing huge loss of economy. Diseased leaves of Bambusa pallida were used for isolation of fungal assemblages in symptom sites. A total of 7 fungi were isolated from the cultured medium; these were Lasiodiplodia theobromae, Drechslera rostrata, Curvularia lunata, Fusarium redolens, Sterile sp1, Sterile sp2, and Sterile sp3. Isolated L. theobromae, D. rostrata, C. lunata, F. redolens may be the causal fungi for necrotic spots disease in B. pallida. Colonization rate and isolation rate (\%) were observed highest in L. theobromae, C. lunata F. redolens and Sterile sp2. The present finding will be helpful for knowing the causes of damage and relation with leaf spot disease. Further studies needed to be undertaken for finding the mode of colonization to causes diseases.
\end{abstract}

Keywords: Bamboo, Disease, Isolated, Colonization rate and Isolation rate.

\section{Introduction}

Bamboos are woody perennial grass belong to family Poaceae. Bamboos are known as 'poor man's timber' in India and play an important role in the rural livelihood and economy. In India, there are about 128 species of bamboo belonging to 23 genera and covering an area of 10.3 million hectares (Tiwari, 1991) but 19 species are recorded in Tripura (Forest department of Tripura, 2018). Of these, the Northeastern region has 15 genera and 90 species covering 29,396 sq $\mathrm{km}$ which comprises of about $28 \%$ of total bamboo growing areas in the country (Anonymous, 2005). In Tripura bamboo is used in various ways like in traditional use, household, craft making, house making, furniture making, and fencing or in more various purposes. Bamboos have a wide range of societal and industrial uses as food, building material, highquality paper, and soil conservation (Basumatary et al., 2015; Nath et al., 2009).

More than 1100 species of fungi have been described or recorded world-wide from bamboo and include ca. 630 ascomycetes, 150 basidiomycetes and 330 mitosporic taxa and most taxa have been recorded from Asia, with relatively fewer known from India and South America (Hyde et al., 2002). Bamboo is affected by many diseases, among these rot and blight diseases are most serious which were also reported from Bangladesh

${ }^{*}$ Corresponding Author:

Sanjit Debnath,

Research Scholar,

Mycology and Plant Pathology Laboratory,

Department of Botany, Tripura University,

Suryamaninagar-799 022, Tripura, India.

E-mail: sanjitdebnath2888@gmail.com
(Gibson, 1975; Rahman, 1978). In India, blight disease was reported from the state of Kerala and Orissa (Jamaluddin et al., 1992). The Disease development is mainly depends on three conditions, these are susceptible host plant, favorable environment, and an active, living pathogen must be present (Pscheidt and Ocamb, 2016). Therefore, majority of cases fungal infection causes necrosis of the host plant tissue and showed some abnormality in plant. Endophytic fungal population varies from plants to plants, species to species, region to region but also differs with change in climatic conditions of the same region (Nair and Padmavathy, 2014). Matured leaves had greater number of genera and species, with higher colonization frequency, than those in the young leaves and fungal occurrence in leaves increased during rainy season i.e., July to September (Chareprasert et al., 2006; Thongsandee et al., 2012).

B. pallida is one of the most important bamboo of Northeast, it occurs in Arunachal Pradesh, Assam, Meghalaya, Nagaland and Tripura of North east India and it is mainly used for making of baskets, mats, toys, wall plates, screen and wall hangers making (Gupta and Ranjan, 2016). The leaf spot disease of $B$. pallida was selected because, the majority of pathogenic bamboo fungi have been reported from leaves with few records from culms

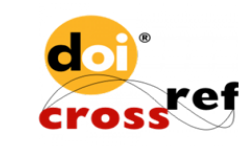


and leaf spot diseases caused by several species of Phyllachora are one of the most common diseases of bamboo (Boa, 1967; Parbery, 1967). Information about disease causing fungi from different parts of bamboo is incomplete. Therefore, isolation and identification of fungi from different parts of bamboos is still an essential step towards understanding ecosystem communities (Hyde et al., 2002).

The work was an attempt to find out the assemblages of fungal assemblages in the symptom site with a view to get knowledge about the exact disease-causing fungi.

\section{Materials and Methods}

Site description and collection: Identification characteristics of $B$. pallida were distinct nodes are not prominent, conical culm sheath with conical blade longer then the sheath, small bristled auricles and narrow ligule. Diseased leaf of B. pallida was collected from Tripura University Bamboo Setum of BCRU, Suryamaninagar, West Tripura (Fig. 1) on August, 2017. Sample was transported in closed sterile polythene bags and processed within $24 \mathrm{hrs}$ of collection in laboratory.

Sterilization of glassware and chemicals: Media and glassware other than petridishes were sterilized in an autoclave at a pressure of $15 \mathrm{lbs}$ for $30 \mathrm{~min}$. Petridishes were sterilized in a hot air oven at $160^{\circ}$ C for 3 hr.

Surface sterilization and preparation of plant material: Segments of lamina were taken from the infected portion of fresh infected leaves with the help of sterile scissor. All the segments were about $1 \mathrm{~cm}^{2}$ in size. All segments were dipped in $70 \%$ ethanol for 5 seconds than rinsed in sterile distilled water for 10 seconds (Luginbuh and Muller, 1980; Kreise and Schauer, 1987).

Preparation of Media: Malt Extract Agar (Malt$3 \mathrm{~g} / \mathrm{L}$, Peptone- $1.5 \mathrm{~g} / \mathrm{L}$ and Agar- $6 \mathrm{~g} / \mathrm{L}$ ) and Potato Dextrose Agar (Potato-20g/L, Dextrose$20 \mathrm{~g} / \mathrm{L}$ and Agar-15g/L) media was used for the culture. The media was sterilized in an autoclave at 15 psi for 20 minutes after cooling $10 \mathrm{mg}$ of antibiotic $(150 \mathrm{mg} / \mathrm{l}$ of streptomycin) was added for prevention of contamination of bacteria. The media was then poured into the sterile plates.

Inoculation: Inoculation was done under laminar air flow. Root and rachis of the samples were dipped into the Tween-20 solution for 10 minutes to make them soften. Further, the samples were dipped in sodium hypo-chloride solution for 5 minutes. After that, samples were allowed to dipped into alcohol for 2 minutes and these were washed with distilled water until the foam removed. Similarly, rhizome and rachis of the samples were dipped into sodium hypo-chloride solution for 5 minutes, then dipped into alcohol for $2 \mathrm{~min}$ and then washed with distilled water. The prepared samples were placed in the petridishes by teasing them with sterile needle and forceps in triplicate manner for each sample and were kept for at $25^{\circ} \mathrm{C}$ for 7 days or more until the colonies grew. Fungi growing out from the samples were subsequently transferred onto fresh malt extract agar tubes with the help of inoculation loop. The procedure of transferring to fresh malt extract agar plates were carried out for several times in order to isolate pure colonies.

Identification of fungi: The colonies were then identified with staining by cotton blue and Lactophenol under a compound microscope OLYMPUS CX21i. The fungal specimens were identified by using the following laboratory manual (Ellis, 1971; Domsch et al., 1980; Watanabe et al., 2002).

Data analysis: Colonisation rate and isolation rate were calculated by the following formula (Petrini and Fisher, 1988):

Colonisation rate $=$ Total number of segments from which fungi were isolated in a sample/ total number of segments used for isolation $\times 100$ (1)

Isolation rate $(\%)=$ Number of segments from which a given species was isolated / total number of segments used for isolation $x$

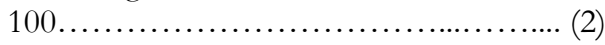

\section{Results}

Observation on infected leaves: Leaf spot disease appeared as doted or linear spots on leaf. The size of the spots varied (1-4 mm) and black in colour at mature stage of development. At immature stage spot was small in size $(1 \mathrm{~mm})$ and light yellow in colour. Spots or blotches that are located linearly around the whole leaf and converted to chlorosis. After chlorosis the leaf was converted to dark yellow and drops prematurely (Fig. 2A).

Isolation of fungi: The fungi isolated from infected leaf of $B$. pallida which was inoculated in Malt Extract Agar (MEA) media, incubated for 5-6 days in a incubator till it grew into mature colonies (Fig. 2C-F). In the present study, fungal strains were isolated from the infected disease parts of B. pallida. A total of 7 fungi were isolated, which were belonging to different family. Numbers of Isolates were shown in Table 1 and Fig. 3. 


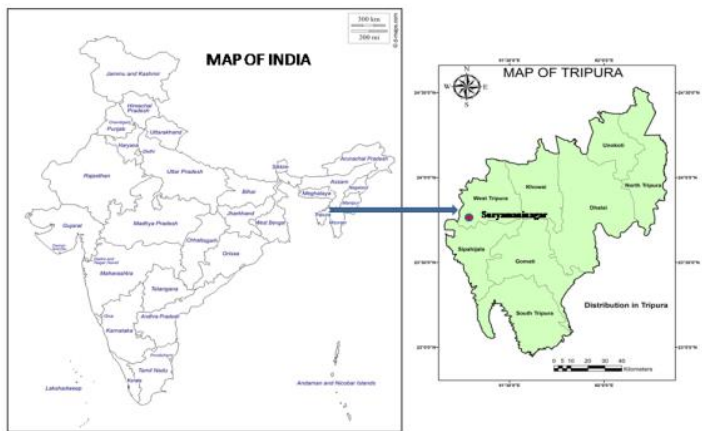

Figure 1. Field location of B. pallida.
Identification of fungi: The identified species of fungi mainly belong to Ascomycota. The isolated genera of fungi were identified on the basis of microscopic characters (Table 1) and isolated genera were; Lasiodiplodia theobromae, Drechslera rostrata, Curvularia lunata, Fusarium redolens, Sterile sp1, Sterile sp2 and Sterile sp3, respectively (Fig. 3). Spores of isolated fungi are shown in Fig. 3.

Colonization and isolation rate: Number of colonies of fungi isolated from infected leaf of $B$. pallida were shown in Table 1. Maximum number of colonisation rate (2 nos) and maximum isolation rate $(22.22 \%)$ were observed from $L$. theobromae, $C$. lunata, F. redolens and Sterile sp2.
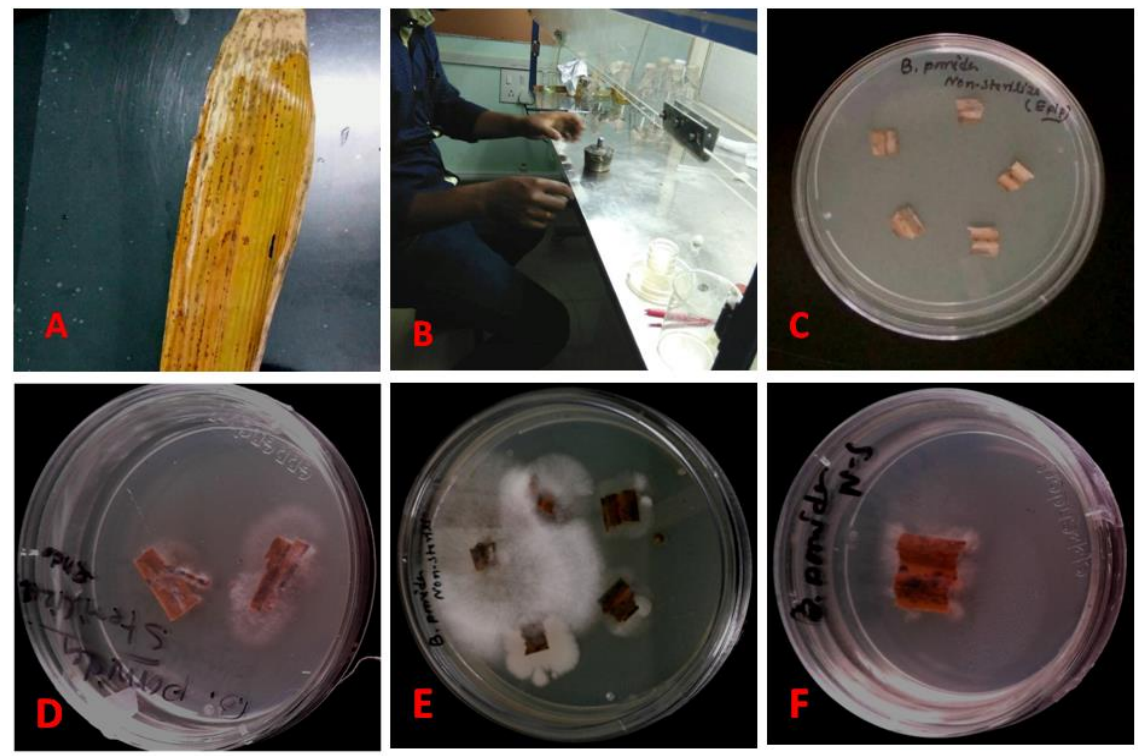

Figure 2. A: Diseased leaf of B. pallida, B: Inoculation of infected leaf in sterile condition, C: After inoculation (1 st day), D, E,F: Showed fungal growth after 4-5 days of inoculation.

Table 1. Microscopic characters, colonisation rate and isolation rate of isolated fungi from infected leaf (diseased) of B. pallida.

\begin{tabular}{|c|c|c|c|c|}
\hline $\begin{array}{l}\text { Sl. } \\
\text { No. }\end{array}$ & Isolated fungi & Microscopic characters & $\begin{array}{l}\text { Colonisation } \\
\text { rate }\end{array}$ & $\begin{array}{l}\text { Isolation } \\
\text { rate }(\%)\end{array}$ \\
\hline 1. & $\begin{array}{l}\text { Lasiodiplodia theobromae } \\
\text { (Pat.) Griffon \&Maubl. }\end{array}$ & $\begin{array}{l}\text { Conidia are sub-ovoid to ellipsoid-ovoid, apex rounded, } \\
\text { sometimes tapering to a truncate base, thick-walled and with } \\
\text { granular contents. Initially conidia are hyaline and aseptate, } \\
\text { becoming dark brown and one-septate. }\end{array}$ & 2 & 22.22 \\
\hline 2. & 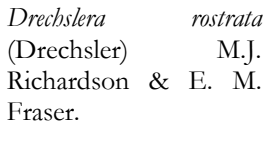 & $\begin{array}{l}\text { Conidia are straight to slightly curved, ellipsoidal to narrowly } \\
\text { obclavate or rostrate, brown or olivaceous, thick-walled, except } \\
\text { in a small subhyaline region at the apex and basal septum darker } \\
\text { and thicker than the other septa. }\end{array}$ & 1 & 11.11 \\
\hline 3. & $\begin{array}{l}\text { Curvularia lunata } \\
\text { (Wakker) Boedijn. }\end{array}$ & $\begin{array}{l}\text { Conidiophores erect, straight to flexuous, septate, often } \\
\text { geniculate Conidia are ellipsoidal, often curved or lunate, } \\
\text { rounded at the ends or sometimes tapering slightly towards the } \\
\text { base, pale or dark brown. }\end{array}$ & 2 & 22.22 \\
\hline 4. & $\begin{array}{l}\text { Fusarium } \\
\text { Wollenw. }\end{array}$ & $\begin{array}{l}\text { Ascospores, which varied in shape and were occasionally single- } \\
\text { cell. }\end{array}$ & 2 & 22.22 \\
\hline 5. & Sterile sp1 & & 1 & 11.11 \\
\hline 6. & Sterile sp2 & $\begin{array}{l}\text { This group of fungi does not produce any known sexual or } \\
\text { asexual spores. Myceliums are white or black in colour. }\end{array}$ & 2 & 22.22 \\
\hline 7. & Sterile sp3 & & 1 & 11.11 \\
\hline
\end{tabular}




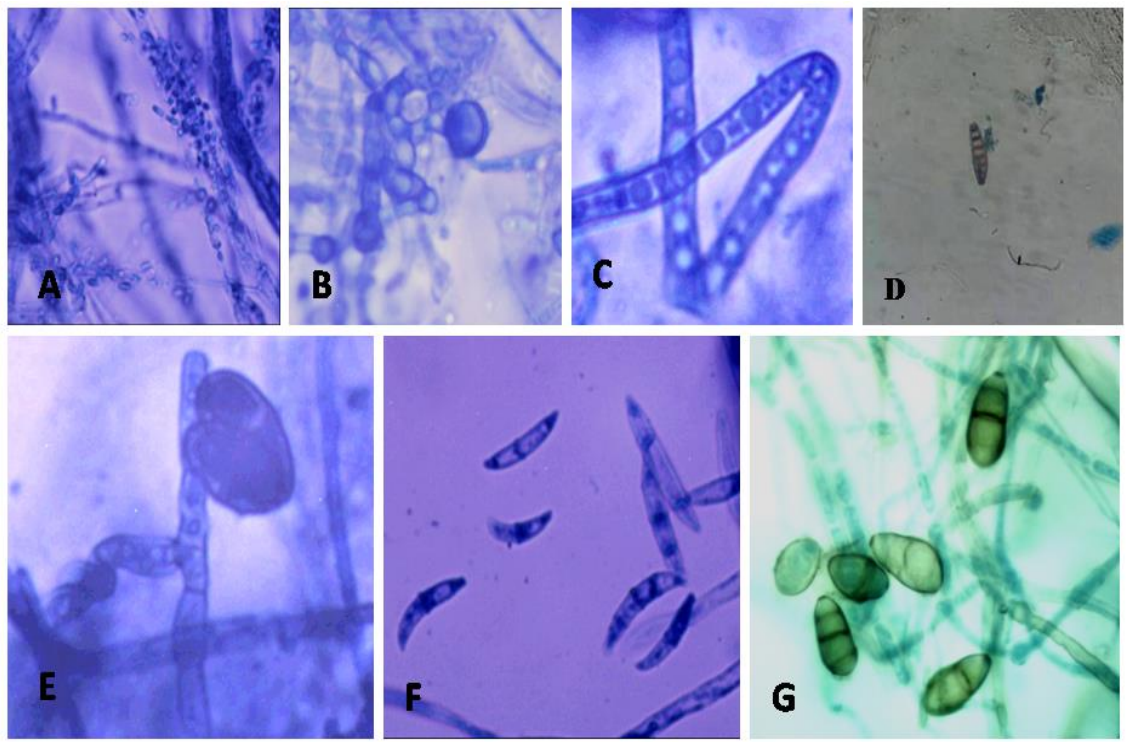

Figure 3. Showed different fungal isolates from disease leaf of bamboo. A: Sterile sp1, B: Sterile sp2, C: Sterile sp3, D: D. rostrata, E: L. theobromae, F: F.redolens and G: C. lunata.

\section{Discussion}

The present study dealt with the isolation and identification of fungal assemblage in B. pallida. A total of four fungi and three sterile forms were isolated in the present investigation. It was observed that out of seven isolates three fugal species were dominant, which might be mainly due to speckle of disease in $B$. pallida. In present study, fungus isolated from leaf of $B$. palida was also recorded by different workers from different parts of plant from all over the world. Petrakomyces indicus a diseasecausing fungus of Bambusa sp. reported from Tamil $\mathrm{Nadu}$ and Karnataka (Subramanian and Ramakrishnan, 1985; Rangaswami et al., 1970).

Earlier reports suggested that most of the fungal isolates causing disease among different plants. Fungal pathogen Fusarium sp. effect a wide variety of hosts at any age of plants. Fusarium species is a main causal agent for different plant diseases, like, barley (Leslie and Summerell, 2006), wheat (Gilbert and Fernando, 2004), soybean (Pioli et al., 2004), potatoes (Ali et al., 2005), maize (Leslie and Summerell, 2006), sorghum (Menkir et al., 1996). F. semitectum caused both blight and rot diseases in $B$. tulda. F. moniliforme and F. oxysporum causes preemergence damping-off, which was also similarly found in B. bambos, Dendrocalamus strictus, D. brandisii, D. longispathus, D. membranaceus and Typhlops siamensis (Gogoi et al., 2010; Mohanan, 1994). Drechslera rostrata and Exserobilum halodes, these two closely related fungi were reported as causal factor for causing foliage blight in bamboo, especially in nurseries and plantations stage (Harsh et al., 1989; Bhat et al., 1989). F. avenaceum are the dominant epiphytic fungi while isolated from both diseased and healthy leaves of B. bambos (Li et al., 2012).
Curvularia species causes disease and their effects ranges from seedling failure to leaf blight in several plant species (Khasanov et al., 1990). C. lunatausually causes different diseases in maize, and also seedlings of B. bambos (Mohanan, 1994; Akinbode, 2010). D. sorokiniana, the causal agent of spot blotch of wheat which causing considerable yield losses and it is a predominant pathogen in North-eastern India (Mandal et al., 1999).

It has been recognized that species of the Botryosphaeriaceae and Lasiodiplodia sp. are important pathogens of several plants (Arx, 1987) and found predominantly throughout tropical and subtropical regions (Burgess et al., 2006). L. theobromae causes black rot disease on Kenaf Seeds in Malaysia and causes infections on healthy Euphorbia ingens trees in South Africa (Norhayati et al., 2016; van der Linde et al., 2011). L. theobromae infect the mangrove plants and it was a major limiting factor affecting cashew nut production in Nigeria (Ukoima, 1996).

In the present study we also found sterile forms as fungi that were distinguished based on the culture characteristics. The presence of sterile forms as endophytes continues to frustrate mycologists because of their uncertain taxonomy (Bills, 1996). Sterile forms have been recorded from many other angiosperm hosts also and due to their sterile nature they are not responsible for causing diseases in bamboo. From the above discussion the isolates $D$. rostrata, $L$. theobromae, $F$. redolensand $C$. lunataare reported to be the disease-causing fungi in different plant symbiotic life style. So, the present finding revealed that $D$. rostrata, $L$. theobromae, $F$. redolens and C. Iunatamay be the causal organisms of leaf spot 
disease of B. pallida. Such fungi which are isolated from the leaf spot sites may be in the continuum mode of association with $B$. pallida.

\section{Conclusion}

Bambusa pallida is one of the highly used species of bamboo in Northeast, India and it is considered the mainstay of the socio-cultural fabric of people of Tripura. However, the bamboo clumps are affected by the occurrence of blight, rot diseases, leaf spot diseases and reducing clump producing. The present finding will be helpful for knowing the causes of leaf spot disease of $B$. pallida. Further studies needed to be undertaken for effective management and control of leaf spot diseases in order to prevent from spreading of infection in the nearly clumps.

\section{Acknowledgements}

The authors are grateful to the Head and Coordinator of BCRU, Department of Botany for providing all sorts of facilities. The first author is thankful to the Department of Biotechnology (DBT), Government of India for the financial assistance.

\section{References}

1. Tiwari DN. A monograph on bamboo. International Book Distributors, Dehra Dun, India. (1991) pp. 498.

2. Tripura Forest Department. Developed \& Hosted by Directorate of Information Technology, Govt. of Tripura, India. (2018).

3. Anonymous. Distribution of bamboo in North-East India. (2005). http// www.ifs.nic.in.

4. Basumatary A, Middha SK, Talambedu U, Brahma BK and Goyal AK. Bamboo, as potential sources of food security, economic prosperity and ecological security in North-East India: an overview. Res Plant Biol, 5.2 (2015) pp. 17-23.

5. Nath AJ, Das $G$ and Das AK. Traditional knowledge base in the management of village bamboos: A case study in Barak Valley, Assam, Northeast India. Indian J Tradit Know, 8.2 (2009) pp. 163-168.

6. Hyde KD, Zhou DQ and Dalisay T. Bambusicolous fungi: A review. Fungal Divers, 9 (2002) pp. 1-14.

7. Gibson IAS. Report on a visit to the republic of Bangladesh. Overseas Development Administration, London, U.K. (1975) pp. 28.

8. Rahman MA. Isolation of fungi from blight affected bamboos in Bangladesh. Ban Bigyan Patrika, 7 (1978) pp. 42-49.

9. Jamaluddin, Gupta BN, Bohidarn SC and Dadwal VS. Mortality of bamboo (Bambusa nutans Wall.) in coastal area of Orissa. Journal of Tropical Forestry, 8.3 (1992) pp. 252-261.
10. Pscheidt JW and Ocamb CM. Senior editors, Pacific Northwest Plant Disease Management Handbook, Oregon State Extension Service (2016) pp. 848.

11. Nair D and Padmavathy S. Impact of endophytic microorganisms on plants, Environment and Humans. Sci World J, 1.4 (2014) pp. 1-11.

12. Chareprasert S, Piapukiew J, Thienhirun S, Whalley AJS and Sihanonth P. Endophytic fungi of teak leaves Tectonagrandis L. and rain tree leaves Samanea saman Merr. World Journal of Microbiology and Biotechnology, 22.5 (2006) pp. 481-486.

13. Thongsandee W, Matsuda Y and Ito S. Temporal variations in endophytic fungal assemblages of Ginkgo biloba L. Journal of Forest Research, 17.2 (2012) pp. 213-218.

14. Gupta D and Ranjan R. Role of Bamboo in Sustainable Development. ASJ International Journal of Advances in Scientific Research and Reviews, 2.1 (2016) pp. 25-31.

15. Boa ER. Fungal diseases of bamboo: A preliminary and provisional list. In: Recent Research on Bamboos (eds. A.N. Rao, G. Ohanarajan and e.B. Sastry). Proceedings of the International Bamboo Workshop, Hanzhou, China. The Chinese Academy of Forestry, China and International Development Research Centre, Canada. (1967).

16. Parbery DG. Studies on graminicolous species of Phyllachora Nke. in FckI. V, A taxonomic monograph. Aust J Bot, 15 (1967) pp. 271-375.

17. Luginbuh LM, Muller E. EndophytischePilze in den oberirdischenOrganen von 4 gemeinsamangleichen Standortenwachsenden Pflanzen (Buxus, Hedera, Ilex, Ruscus). Sydowia, 33 (1980) pp. 185-209.

18. Kreise LH and Schauer F. Methoden des mykologischenLaboratoriurns, Gustav Fischer Verlag: Jena. (1987).

19. Ellis MB. Dematiaceous Hyphomycetes, Common wealth Mycological Institute: Kew, Surrey, UK (1971).

20. Domsch KH, Gams W and Anderson TH. Compendium of soil fungi: vol.1. London: Academic Press. 7 (1980) pp. 859.

21. Watanabe T. Pictorial Atlas of Soil and Seed Fungi Morphologies of Cultured Fungi and Key to Species, Second Edition, CRC Press. (2002).

22. Petrini $O$ and Fisher PJ. A comparative study of fungal endophytes in xylem and whole stem of Pinus sylvestris and Fagus sylvatica. Trans Br Mycol Soc, 19 (1988) pp. 233-238

23. Subramanian CV and Ramakrishnan K. Petrakomyces, a new genus of Sphaeropsidales. Proc IndAcad sci, 37 (1953) pp. 110-113. 
24. Rangaswami G, Sheshadri VS and Lucy Channamma KK. Fungi of South India, Univ. of Agric. Sci. Bangalore, (1970) pp. 193.

25. Leslie JF and Summerell BA. The Fusarium Laboratory Manual. Ames, Blackwell Publishing, (2006) pp. 369.

26. Gilbert JRL and Fernando WGD. Epidemiology and biological control of gibberellazeae/Fusarium graminearum. Can J Plant Pathol, 26 (2004) pp. 464472.

27. Pioli RN, Mozzoni L and Morandi EN. First report of pathogenic association between Fusarium graminearum and soybean. Plant Dis, 88 (2004) pp. 220.

28. Ali S, Rivera VV and Secor GA. First report of Fusarium graminearum causing dry rot of potato in North Dakota. Plant Dis, 89 (2005) pp. 105.

29. Menkir A, Ejeta G, Butler LG, Melakeberhan A and Warren WH. Fungal invasion of kernels and grain mold damage assessment in diverse sorghum germplasm. Plant Dis, 80 (1996) pp. 1399-1402.

30. Gogoi J, Borah RK and Lahan JP. A preliminary investigation of certain bamboo diseases in Dhemaji district of Assam. Journal of Nature and Environment, 2.3 (2010) pp. 50-53.

31. Mohanan C. Diseases of Bamboos and Rattans in Kerala, Kerala Forest Research Institute Peechi. Thrissur Research Report 98 (1994) pp. 120.

32. Harsh NSK, Nath V and Tiwari CK. A common foliar disease of Dendrocalamus strictus in nurseries, Proc. Seminar on Silviculture and Management of bamboos, Dec. 13-15. IDF, Jabalpur. (1989).

33. Bhat MN, Hegde RK, Hiremath PC and Kulkarni S. Unrecorded pathogen on bamboo causing blight in India. Curr Sci, 58.2 (1989) pp. 1148-1149.

34. Li S, Peng Y, Zhu T, Zhu H, Mao C and Qiao T. Diversity of epiphytic fungi on the diseased and healthy leaves of Bambusa. Afr J Microbiol Res, 49.6 (2012) pp. 7556-7563.

35. Khasanov BA, Shavarina ZA and Vypritskaya AA. Characteristics of Curvularia Boedijn fungi and their pathogenicity in cereal crops. Mikol Fitopatol, 24 (1990) pp. 165-173.

36. Akinbode OA. Evaluation of antifungal efficacy of some plant extracts on Curvularia lunata, the causal organism of maize leaf spot. Afr J Environ Sci Technol, 4.11 (2010) pp. 797-800.

37. Mandal S, Srivastava KD, Aggarwal $\mathrm{R}$ and Singh DV. Mycoparasitic action of some fungi on spot blotch pathogen (Drecbslera sorokiniana) of wheat. Indian Phytopath, 52.1 (1999) pp. 39-43.

38. Arx J A von. Plant-pathogenic fungi, Cramer, Berlin. (1987) pp. 288.

39. Burgess TI., Barber A, Mohali S, Pegg G, De Beer $\mathrm{W}$ and Wingfield MJ. Three new Lasiodiplodia spp. from the tropics, recognized based on DNA sequence comparisons and morphology. Mycologia, 98.2 (2006) pp. 423-435.

40. Norhayati M, Erneeza $\mathrm{MH}$ and Kamaruzaman S. Morphological, pathogenic and molecular characterization of Lasiodiplodia theobromae: a causal pathogen of black rot disease on kenaf seeds in Malaysia. Int J Agric Biol, 18 (2016) pp. 80-85.

41. van der Linde JA, Six DL, Wingfield MJ and Roux J. Lasiodiplodia species associated with dying Euphorbia ingens in South Africa. South Forests, 73. 3\&4 (2011) pp. 165-173.

42. Ukoima HN. Studies on Fungi Associated with some Mangrove Forest Trees in Rivers State, Ph.D Thesis, Rivers State University of Science and Technology, Nigeria. (1996).

43. Bills GF. Isolation and analysis of endophytic fungal commumtIes from woody plants. In: Endophytic fungi in grasses and woody plants (eds. S.C.Redlin and L.M.Carris), APS Press, St. Paul, Minnesota, U.S.A. (1996) pp. 31-65.

\section{Cite this article as:}

Sanjit Debnath, Pintu Karmakar, Sukla Bhattacharjee, Koushik Majumdar, Panna Das and Ajay Krishna Saha. Isolation and identification of fungal assemblages in the necrotic spots of Bambusa pallida (L.) Voss. Annals of Plant Sciences 7.4 (2018) pp. 2160-2165.

do $\mathrm{http://dx.doi.org/10.21746/aps.2018.7.4.15}$

\section{Source of support: DBT, Government of India Conflict of interest: Nil}

